\title{
Rasfonin, a novel 2-pyrone derivative, induces ras-mutated Panc-1 pancreatic tumor cell death in nude mice
}

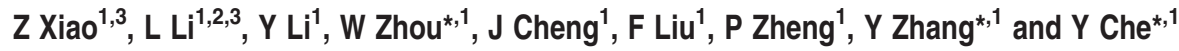

Rasfonin is a novel 2-pyrone derivative reported to induce apoptosis in ras-dependent cells. In this study, its effects on rasmutated pancreatic cancer cells were investigated in vitro and in vivo. Two human pancreatic cancer cell lines Panc-1 (mutated K-ras) and BxPC-3 (wild-type K-ras) were selected to test the effects of rasfonin on cell proliferation, clone formation, migration and invasion in vitro. Immunoblotting was used to detect the expressions of EGFR-Ras-Raf-MEK-ERK signaling pathway proteins. Ras activity was measured using a pull-down ELISA kit and guanine exchange factor (GEF)/GTPase-activating proteins (GAP) activity was measured by [ $\left.{ }^{3} \mathrm{H}\right]$-GDP radiometric ligand binding. For an in vivo study, $\mathrm{CD} 1$ nude mice bearing Panc-1 cells were treated with rasfonin or Salirasib (FTS). We found that rasfonin suppressed proliferation more strongly in Panc-1 cells $\left(\mathrm{IC}_{50}=5.5 \mu \mathrm{M}\right)$ than BxPC-3 cells $\left(\mathrm{IC}_{50}=10 \mu \mathrm{M}\right)$ in vitro. Clone formation, migration and invasion by Panc-1 cells were also reduced by rasfonin. Rasfonin had little effect on the farnesylation of Ras, but it strongly downregulated Ras activity and consequently phosphorylation of c-Raf/MEK/ERK. Further experiments indicated that rasfonin reduced Son of sevenless (Sos1) expression but did not alter GEF and GAP activities. The in vivo experiments also revealed that rasfonin $(30 \mathrm{mg} / \mathrm{kg})$ delayed the growth of xenograft tumors originating from Panc-1 cells. Tumor weight was ultimately decreased after 20 days of treatment of rasfonin. Rasfonin is a robust inhibitor of pancreatic cancers with the K-ras mutation. The reduction of Sos1 expression and the consequently depressed Ras-MAPK activity could be important in its anticancer activity.

Cell Death and Disease (2014) 5, e1241; doi:10.1038/cddis.2014.213; published online 22 May 2014

Subject Category: Experimental Medicine

Cancer is projected to become the leading cause of mortality worldwide in 2010 and cancer cases are expected to double by 2020. Pancreatic cancer is the fourth leading cause of cancer mortality in the USA, accounting for $6 \%$ of all cancer deaths. In the USA, the estimated number of new cases of pancreatic cancer in 2009 was 42000, with an estimated 35000 deaths. The current 5 -year survival rate is $5 \%$. In the $\mathrm{EU}$, pancreatic cancer is the fifth leading cause of mortality, accounting for approximately $7 \%$ of all cancer deaths per year. ${ }^{1}$ Gemcitabine has been a standard treatment for advanced pancreatic cancer since it was found a decade ago to result in a better clinical response and survival than bolus 5-fluorouracil. However, its curative effect is far from satisfactory when used alone, because patients succumb to their disease in $<6$ months. ${ }^{2,3}$

Ras is a family of genes involved in regulating cell proliferation, differentiation, adhesion and apoptosis. Each mammalian cell contains at least three genes, $H$-ras, $K$-ras and $N$-ras. Generally speaking, to acquire malignancy, pancreatic cancer cells undergo a series of sequential genetic mutations. Among the initial events are K-ras mutation. ${ }^{4-6}$
It has been reported that $\mathrm{K}$-ras gene mutation occurs in more than $90 \%$ of pancreatic cancers. ${ }^{7}$ This mutation results in constitutive activation of the protein, which no longer requires a ligand for activation. In fact, many growth factors and mitogens use the Ras/Raf/MEK/ERK signaling cascade to transmit signals from their receptors. After cytokines, growth factors or mitogens have bound to their appropriate receptors, the coupling complex growth factor receptor-binding protein 2 (Grb2)/Son of sevenless (Sos1) is activated. Sos1, the membrane-associated guanine exchange factor (GEF), shifts the equilibrium from inactive Ras-GDP to the active Ras-GTP form. ${ }^{8-10}$ Importantly, growth factor receptor-binding protein 2 (Grb2), through its SH3 motif, binds and transports Sos1 to the plasma membrane to initiate Ras activation. ${ }^{8,9}$ The GTPbound active Ras can then recruit Raf to the cell membrane, sequentially activating the MAP kinases. Dynamic termination of growth signaling occurs when Ras, through its intrinsic GTPase activity, cycles back to its GDP-bound, inactive state. Intrinsic Ras-GTPase activity is stimulated by GTPase-activating proteins (GAPs). ${ }^{11,12}$

\footnotetext{
'Beijing Institute of Pharmacology and Toxicology, Beijing 100850, China and 2Department of Pharmacology, Logistics College of Chinese People's Armed Police Forces, Tianjin, China

${ }^{*}$ Corresponding author: W Zhou or Y Zhang or Y Che, Beijing Institute of Pharmacology and Toxicology, Road Taiping 27, Beijing 100850, China. Tel: + 861066931625 (WZ or YZ) or + 861066932679 (YC); Fax: + 861068211656 . E-mail: zhouwx@ bmi.ac.cn or zhangyx@ bmi.ac.cn or cheys@ im.ac.cn ${ }^{3}$ These authors contributed equally to this work.

Keywords: rasfonin; ras; pancreatic cancer; sos1; Panc-1 cell

Abbreviations: ANOVA, one-way analysis of variance; FCS, fetal calf serum; FTS, Salirasib; GAP, GTPase-activating proteins; GEF, guanine exchange factor; Grb2, growth factor receptor-binding protein 2; RBD, ras-binding domain; RTKs, receptor tyrosine kinases; Sos1, Son of sevenless

Received 25.2.14; revised 31.3.14; accepted 31.3.14; Edited by A Stephanou
} 
Rasfonin (Figure 1) is a novel 2-pyrone derivative isolated from the fermented mycelium of Talaromyces species $3656-\mathrm{A} 1 .{ }^{13}$ It is named after the protein Ras since its biological activity is elicited in cells that depend on Ras for growth. Recent studies have indicated that rasfonin selectively destroys ras-dependent $\mathrm{Ba} / \mathrm{F} 3-\mathrm{V} 12$ cells with an $\mathrm{IC}_{50}$ of $0.37 \mu \mathrm{M}$. Exposure to higher concentrations of rasfonin $(2.3 \mu \mathrm{M})$ resulted in a considerable number of cells exhibiting condensed chromatin and fragmented nuclei, the typical markers of apoptosis. However, a non-ras-dependent cell line was unaffected by rasfonin at concentrations up to $2.88 \mu \mathrm{M}$. The selective inducers of apoptosis in ras-dependent cells could represent a novel class of cancer chemotherapeutics useful for treating tumors expressing constitutively active, mutant ras. ${ }^{14}$ In view of this effect, we presume rasfonin holds further promise for treating K-ras mutation pancreatic cancers. However, the reported methods for synthesizing rasfonin have many disadvantages such as low yield, poor selectivity and complex manipulation problems, and could not provide a simple way of obtaining sufficient of the product for our experiments. We therefore initiated a chemical investigation of the fungus Doratomyces sp. (Genebank accession number JQ284031) isolated from a soil sample collected in April, 2007 on the Qinghai-Tibetan plateau at an altitude above $4347 \mathrm{~m}$, Linzhi, Tibet, China. Its HPLC-PDA fingerprints demonstrated that the major component was rasfonin (Chinese patent: 201110453153.8), and its structure was readily identified by comparing the NMR and MS data with those reported. ${ }^{13}$ Thus we obtained sufficient rasfonin for further research.

In this study, we hypothesized that rasfonin affects the proliferation in K-ras mutant human pancreatic tumor cells by regulating the Ras-MAPK pathway. We first observed its effects on the K-ras mutation Panc-1 pancreatic cancer cell line in vitro, including cell proliferation, contact-independent growth, migration and invasion. We then investigated which signaling molecules were affected by rasfonin to identify its target. Finally, a mouse xenograft model originating from Panc- 1 cells was set up and the therapeutic effects of rasfonin were evaluated in vivo.

\section{Results}

Effects of rasfonin on growth of human cancer cells in vitro. To test the antitumor effects of rasfonin, we used two pancreatic cancer cell lines, BxPC-3 (wild-type K-ras) and Panc-1 (mutated K-ras). The assay involved exposing cells to $1-15 \mu \mathrm{M}$ rasfonin. Rasfonin had little inhibitory effect on BxPC-3 cells at 1 and $5 \mu \mathrm{M}$ (Figure 2a). Even $10 \mu \mathrm{M}$ rasfonin inhibited BxPC-3 cell proliferation by only $\sim 60 \%$ after $40 \mathrm{~h}$ coculture $\left(\mathrm{IC}_{50}=10 \mu \mathrm{M}\right)$. In contrast, $5 \mu \mathrm{M}$ rasfonin inhibited Panc- 1 cell proliferation by approximately $30 \%$ after $24 \mathrm{~h}$ incubation. FTS $(50 \mu \mathrm{M})$ inhibited proliferation a little more strongly than rasfonin during the first $24 \mathrm{~h}$. However, in the following $24 \mathrm{~h}$ of incubation, rasfonin and FTS exhibited almost equivalent depressive effects on Panc-1 cell proliferation, and their maximum effect reached $\sim 70 \%$. The $\mathrm{IC}_{50}$ of rasfonin on Panc-1 cell proliferation was $5.5 \mu \mathrm{M}$. Rasfonin at higher concentrations $(15 \mu \mathrm{M}$ in BxPC-3 cells and $10 \mu \mathrm{M}$ in Panc-1 cells) ultimately caused complete

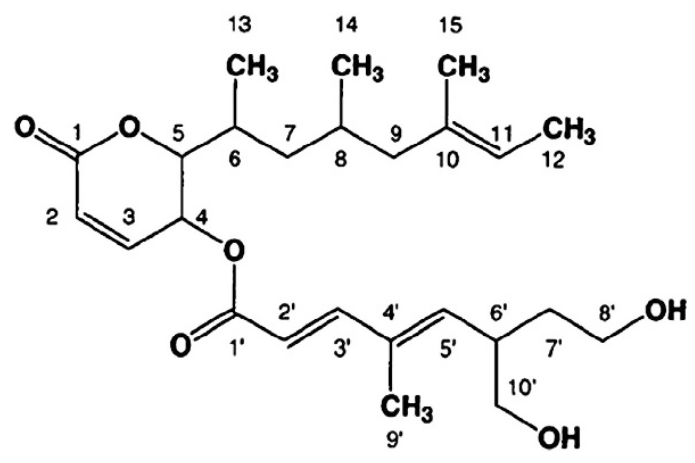

Figure 1 Structure of rasfonin

inhibition of proliferation in both pancreatic cancer cell lines. Similar results were obtained when the experiment was repeated using the MTS assay (Figure $2 b$ ). These results indicate that rasfonin shows relative selective-killing of ras-mutated cancer cells.

Effects of rasfonin on contact-independent growth of Panc-1 cells in vitro. Next, we examined the ability of rasfonin to inhibit the contact-independent growth of human pancreatic cancer cells. First, we investigated the colonyformation capacity of BxPC-3 and Panc-1 cells. We found that BxPC-3 cells alone could not form visible colonies after 8 days of culture, so we only report data on the effect of rasfonin on contact-independent growth in Panc-1 cells. We seeded 1000 Panc-1 cells into the six-well plate with or without rasfonin. On day 8 , the sizes and numbers of colonies were estimated. As illustrated in Figure 2c, $74.1 \%$ of the seeded Panc-1 cells formed visible colonies in the absence of rasfonin. When rasfonin was added at $0.25-1 \mu \mathrm{M}$, colony numbers and size were significantly reduced. When the rasfonin concentration reached $5 \mu \mathrm{M}$, Panc- 1 cells formed no visible colonies. These results suggest that rasfonin suppresses contact-independent growth of Panc-1 cells.

Effects of rasfonin on migration and invasion of Panc-1 cells in vitro. Cancer cell migration is the movement of cells from one area to another, generally in response to chemical signals, and is important for cancer cell differentiation and metastasis. As in the colony-formation assay, we first investigated the migration and invasion capacities of BxPC-3 and Panc-1 cells. We found that the migration and invasion signals of BxPC-3 cells were too weak for detection by the xCELLigence system. Thus, we only present the data concerning the effects of rasfonin on the migration and invasion of Panc-1 cells. As illustrated in Figure $2 \mathrm{~d}$, cell migration peaked after $\sim 11 \mathrm{~h}$ of culture. FTS at $50 \mu \mathrm{M}$ caused a significant reduction $(\sim 75 \%)$ of the migratory activity of Panc-1 cells. Rasfonin concentrations from 1 to $30 \mu \mathrm{M}$ caused a dose-dependent reduction of the migratory activity of Panc- 1 cells.

Cell invasion is intrusion into and destruction of adjacent tissues, particularly with respect to cancer cells. As illustrated in Figure 2e, FTS $(50 \mu \mathrm{M})$ also inhibited Panc-1 cell invasion, but its efficacy was lower than that of $15 \mu \mathrm{M}$ rasfonin. 
a

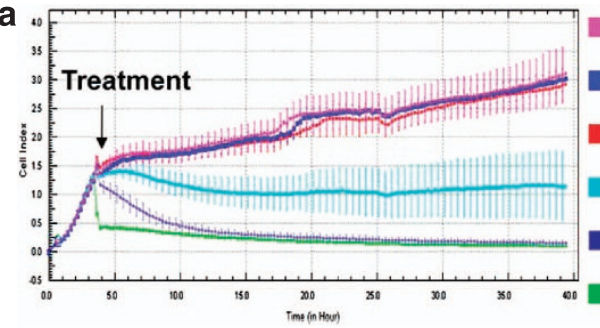

BXPC-3 (wild type K-ras)

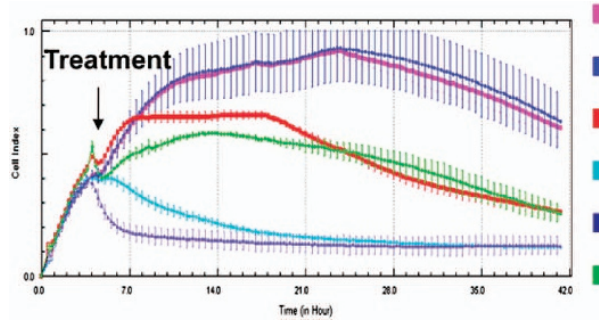

Panc-1 (mutated K-ras)
Control

rasfonin $1 \mu \mathrm{M}$

rasfonin $5 \mu \mathrm{M}$

rasfonin $10 \mu \mathrm{M}$

rasfonin $15 \mu \mathrm{M}$

FTS $50 \mu \mathrm{M}$

Control

rasfonin $1 \mu \mathrm{M}$

rasfonin $5 \mu \mathrm{M}$

rasfonin $10 \mu \mathrm{M}$

rasfonin $15 \mu \mathrm{M}$

FTS $50 \mu \mathrm{M}$ b

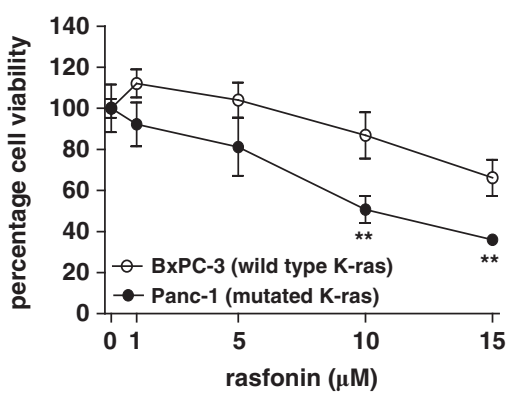

c
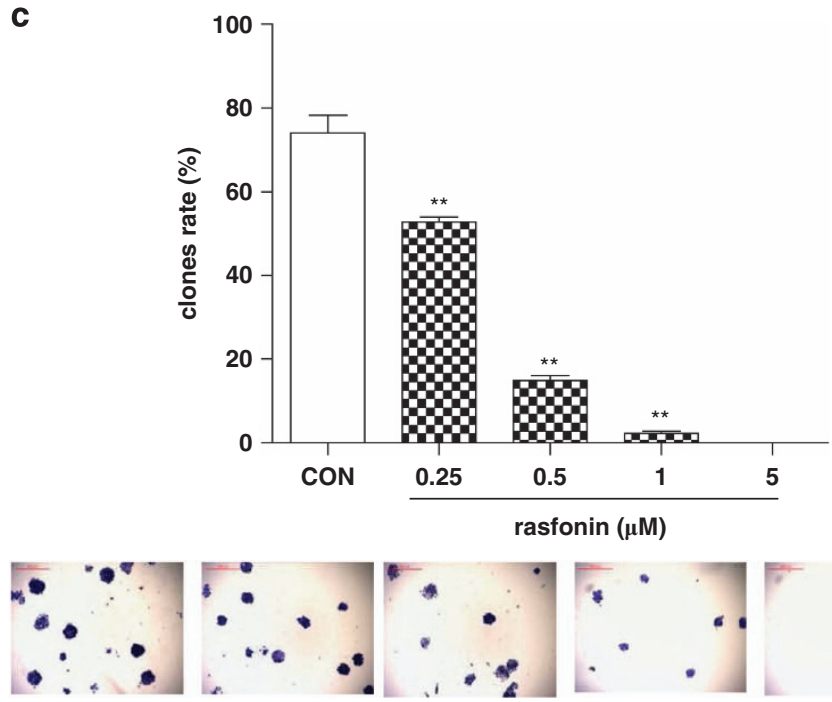

Control

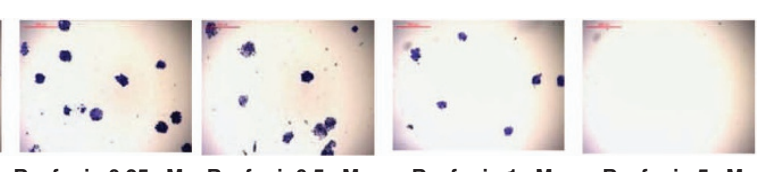

d

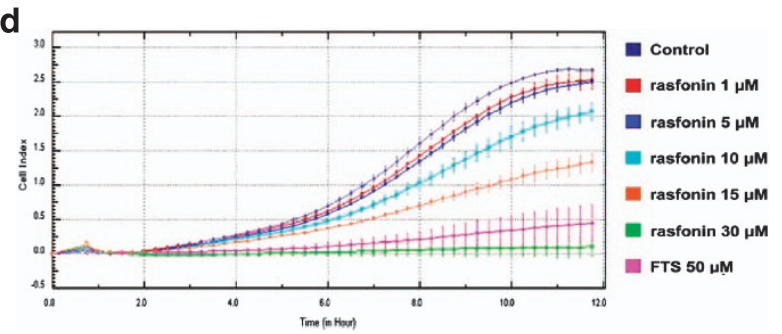

e

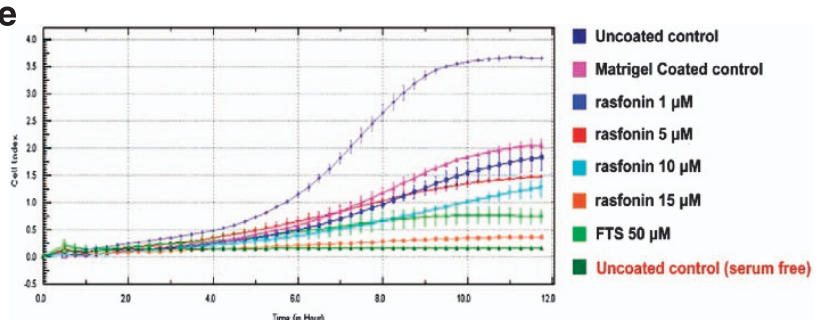

Figure 2 Inhibition growth, contact-independent proliferation, migration and invasion of BxPC-3 and Panc-1 cells by rasfonin. (a) The dynamic effects of rasfonin on adhesion and proliferation of BxPC-3 and Panc-1 cells using the XCELLigence system. BxPC-3 and Panc-1 cells were seeded at a density of 8000 cells/well in 96-well E-Plates, then treated with different concentrations of rasfonin for $40 \mathrm{~h}$. (b) The effects of rasfonin on survival of BxPC-3 and Panc- 1 cells using the MTS assay. Cells were treated with different concentrations of rasfonin for $24 \mathrm{~h}$. The percentage of surviving cell was calculated by normalizing the absorbance value of the treated cells with the absorbance value of the control cells within each cell line. Data are representative of three independent experiments. ${ }^{* *} P<0.01$ versus control, $n=3$. (c) Rasfonin reduced contact-independent proliferation in Panc-1 cells. Panc-1 cells were seeded at 1000 cells per well containing vehicle or various concentrations of rasfonin $(0.25,0.5,1,5 \mu \mathrm{M})$. After 8 days of culture, live colonies were counted and photographed, stained with $0.05 \%$ crystal violet. Bars represent the mean numbers of colonies per field. ${ }^{* *} P<0.01$ versus control, $n=3$. Insets are representative wells. (d) The effects of rasfonin on the migration of Panc-1 cells. Cells with rasfonin or vehicle were seeded on a CIM-plate as described in Materials and Methods. Migration was monitored for $24 \mathrm{~h}$ with the XCELLigence DP system. (e) The effects of rasfonin on the invasion kinetics of Panc- 1 cells in the indicated dilutions of Matrigel using FBS as the chemoattractant. Panc- 1 cells were seeded at $8 \times 10^{4}$ cells per well in either uncoated wells (migration) or Matrigel-coated wells (invasion). Precoating was done at $37^{\circ} \mathrm{C}$ for $4 \mathrm{~h}$ 
Concentration-dependent suppression of cell invasion could also be observed from 1 to $15 \mu \mathrm{M}$ rasfonin.

Effects of rasfonin on Ras expression and activity in Panc-1 cells. The above observations confirmed that rasfonin selectively destroys ras-mutated Panc-1 pancreatic cells. We therefore wondered whether it affects the Ras signaling pathway directly. Panc- 1 cells were first treated with $1-10 \mu \mathrm{M}$ rasfonin and Ras protein expression was investigated by immunoblotting. It was abundantly clear that rasfonin, in contrast to FTS, had only a marginal effect on the expression of farnesylated and unfarnesylated Ras protein, so it had no effect on the modification of Ras protein required for anchoring to the plasmalemma after $12 \mathrm{~h}$ of exposure (Figure 3a). ${ }^{15,16}$

It has been well documented that Ras, in its active-GTPbound state, binds to its downstream kinase c-Raf (MAP Kinase Kinase Kinase) through a domain referred to as the Ras-Binding Domain (RBD). Because rasfonin did not change Ras protein expression, a pull-down assay using a commercial ELISA kit was used to study its effect on Ras-GTP in Panc- 1 cells. This kit takes advantage of the fact that the RBD of Raf- 1 binds preferentially to the activated form of Ras (Ras-GTP). ${ }^{17-19}$ There was background activation of Ras in the Panc-1 cell and EGF stimulation had a modest effect on Ras-GTP levels. Consistent with previous studies, FTS remarkably reduced EGF-induced Ras activation at $50 \mu \mathrm{M} .^{20,21}$ Rasfonin also decreased EGF-induced Ras activation in a dose-dependent fashion, with a maximum effect approximate to that of FTS at $50 \mu \mathrm{M}$ (Figure 3b).

Effects of rasfonin on expression of downstream kinase of Ras in Panc-1 cells. The key signaling pathway from activated Ras is the ERK/MAPK cascade, so we evaluated the phosphorylation of downstream protein kinases in Panc-1 cells by western blotting. Rasfonin clearly inhibited c-Raf, MEK and ERK phosphorylation, but had no significant effect on total MEK and ERK levels (Figure 3c). Consistent with previous studies, FTS at $50 \mu \mathrm{M}$ caused a similar decrease in the expression of ERK-MAPK signaling pathway kinases. ${ }^{22}$ These results indicated that rasfonin and FTS inhibit Ras protein activity and consequent downstream signaling protein activation.

Effects of rasfonin on Ras upstream kinase in Panc-1 cells. The activity of the Ras family is controlled by the ratio of bound GTP to GDP, and because Ras proteins exchange GTP/GDP very slowly and possess a very low intrinsic GTPase activity, these processes are regulated by GEFs and GAPs. GEFs enhance the rate of GDP dissociation, whereas GAPs accelerate the intrinsic Ras-GTPase activity to promote Ras inactivation by several orders of magnitude. We examined the effects of rasfonin on GEF (Grb2/Sos1 complex) and GAP, respectively. ${ }^{8,9}$ Western blotting demonstrated that neither rasfonin nor FTS affected EGF-induced Grb2 or GAP protein expression, but apparently reduced the expression of Sos1 (Figure 4a).

Next, we assayed the GTP/GDP exchange reaction in the presence or absence of rasfonin using a radiolabeled $\left[{ }^{3} \mathrm{H}\right]-$ GDP dissociation and binding assay. As expected, GEF

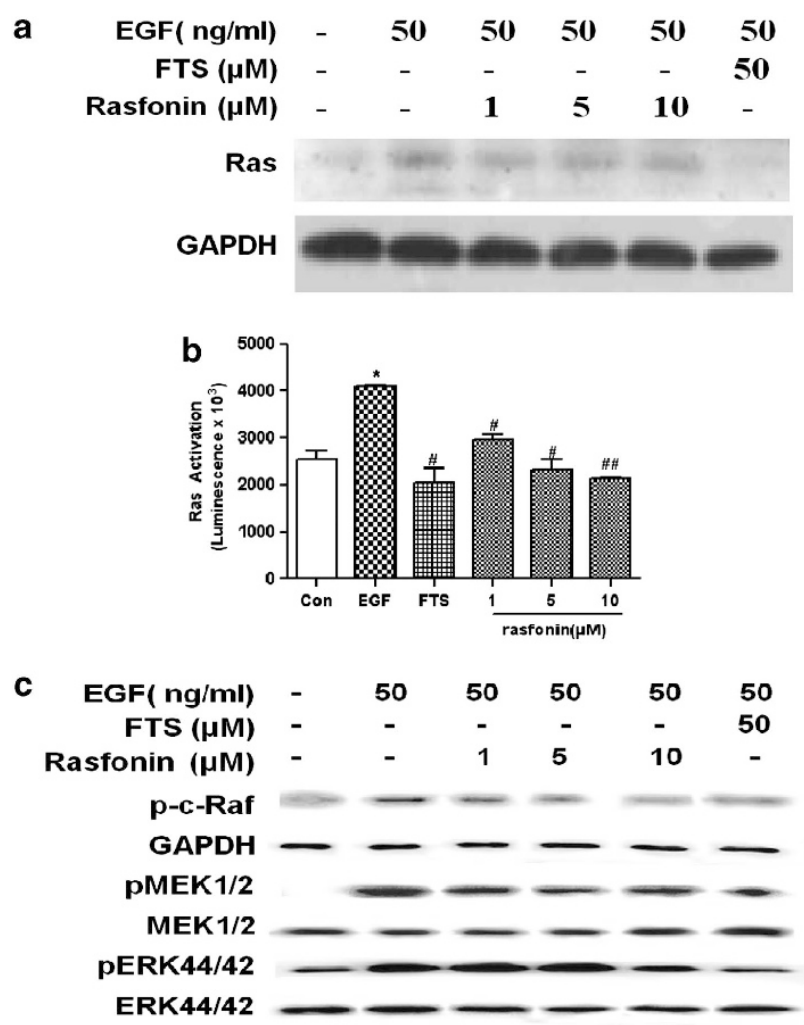

Figure 3 Effects of rasfonin on Ras-MAPK protein expression and activity in Panc-1 cells. (a) Effects of rasfonin on Ras protein expression in Panc-1 cells. Panc-1 cells were cultured in DMEM containing $10 \%$ FBS for $18 \mathrm{~h}$, starved for $9 \mathrm{~h}$ in $0.1 \%$ FBS and then treated with rasfonin at different concentrations $(0,1,5$ and $10 \mu \mathrm{M})$ for $12 \mathrm{~h}$. After that, the cells were stimulated with EGF $(50 \mathrm{ng} / \mathrm{ml})$ for $5 \mathrm{~min}$. Total proteins were extracted and analyzed for Ras protein by immunoblotting. (b) Effects of rasfonin on Ras activity in Panc-1 cells. Cells were handled similarly as mentioned in a. A Ras Activation ELISA assay kit was employed to determine the level of Ras-GTP. Data are representative of one to three independent experiments. Results shown are mean \pm S.D., ${ }^{*} P<0.05$, versus control; ${ }^{\#} P<0.05$, ${ }^{\# \# P} P<0.01$, versus model. (c) Effects of rasfonin on expression of protein kinases involved in the Ras-MAPK signaling pathway in Panc-1 cells. Panc-1 cells were handled similarly as mentioned in a. Total proteins were extracted and analyzed for phosphorylated c-Raf, MEK1/2 and ERK44/42 by immunoblotting. Total MEK1/2 and ERK44/42were also detected as controls

promoted $\left[{ }^{3} \mathrm{H}\right]$-GDP dissociation from Ras in a Ras plus $\left[{ }^{3} \mathrm{H}\right]$-GDP preconditioning system. Preincubation of rasfonin with GEF did not enhance the effect on the dissociation of $\left[{ }^{3} \mathrm{H}\right]$-GDP from Ras (Figure $4 \mathrm{~b}$ ). In respect of GAP activity, the competitive binding of $\left[{ }^{3} \mathrm{H}\right]$-GDP to Ras increased when GAP was added. However, preincubation of rasfonin with GAP did not affect the binding of $\left[{ }^{3} \mathrm{H}\right]-\mathrm{GDP}$ to Ras (Figure $4 \mathrm{c}$ ). The above observations suggest that the inhibition of Ras activity by rasfonin could be related, at least partially, to reduced Sos 1 expression.

Effects of rasfonin on activities of other protein kinases in the EGFR signaling pathway. The EGFR signaling pathway is most important in the spontaneous activation of K-ras. To clarify the selectivity of rasfonin, we chose 19 kinases in the EGFR signaling pathway and investigated their response to rasfonin. These kinases are EGFR, FGFR, PDGFR $\alpha$, PDGFR $\beta$, Flt3, Met, FAK, c-RAF, MEK1, 


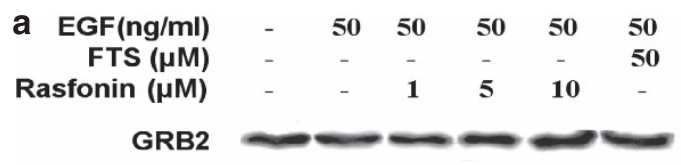

(GEF) Sos1

GAP GAPDH

b

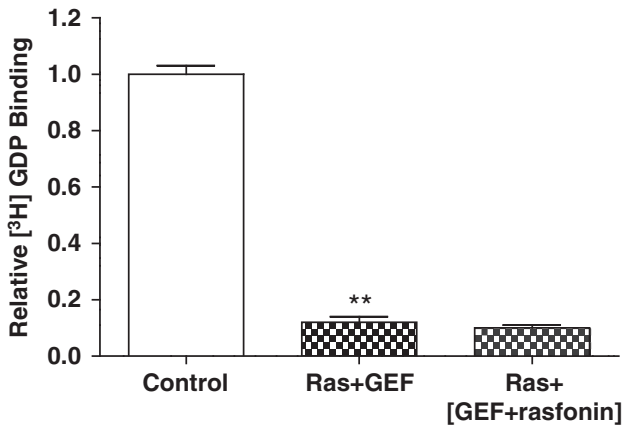

C

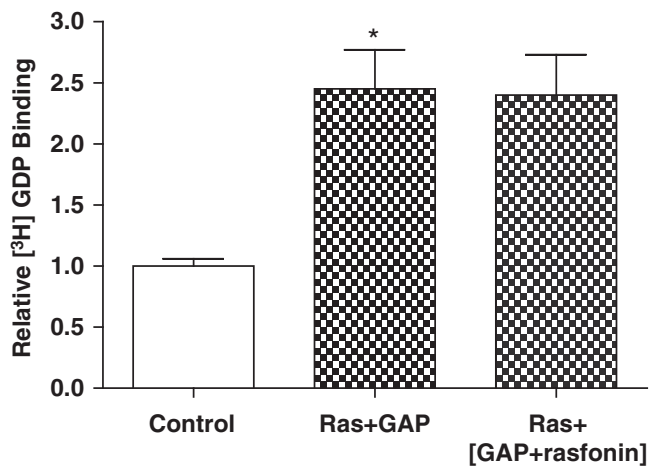

Figure 4 Effects of rasfonin on expression and activity of protein kinases in Ras upstream pathway in Panc-1 cells. (a) Effects of rasfonin on protein kinase expression. Panc-1 cells were cultured in DMEM containing $10 \%$ FBS for $18 \mathrm{~h}$, starved for $9 \mathrm{~h}$ in $0.1 \%$ FBS and then treated with rasfonin at different concentrations $(0,1,5$ and $10 \mu \mathrm{M})$ for $12 \mathrm{~h}$. Total proteins $(40 \mu \mathrm{g})$ were analyzed for Sos1, Grb2 and GAP by immunoblotting. (b) Effects of rasfonin on GEF activity (the dissociation of labeled [ $\left.{ }^{3} \mathrm{H}\right]$-GDP from Ras). Ras was preloaded with $2 \mu \mathrm{Ci}\left[{ }^{3} \mathrm{H}\right]$ GDP, then GEF with or without rasfonin $(10 \mu \mathrm{M})$ was added. The amount of [ $\left.{ }^{3} \mathrm{H}\right]$ GDP bound to Ras was measured by scintillation spectrometry. ${ }^{* \star} P<0.01$, versus control. (c) Effects of rasfonin on GAP activity (the competitive binding of labeled $\left[{ }^{3} \mathrm{H}\right]$-GDP to Ras). Ras was preloaded with $2 \mu \mathrm{Ci}\left[{ }^{3} \mathrm{H}\right]$-GDP and $\mathrm{GTP}$, then GAP with or without rasfonin $(10 \mu \mathrm{M})$ was added. The amount of [ $\left.{ }^{3} \mathrm{H}\right]$-GDP bound to Ras was measured by scintillation spectrometry. ${ }^{\star} P<0.05$, versus control

PI3Kinase, PKB $\alpha, \mathrm{PKB} \beta, \mathrm{PKB} \gamma, \mathrm{IKK} \alpha, \mathrm{mTOR}, \mathrm{p} 70 \mathrm{S6K}$, JNK1 $\alpha 1$, JNK2 $\alpha 2$ and Ros. The $\left[{ }^{32} \mathrm{P}\right]$ radiometric protein kinase assay results indicated that rasfonin at $5 \mu \mathrm{M}$ had only a marginal effect on all the protein kinases we chose except for p70s6k (Table 1). These data suggest that the extent of influence of rasfonin is relatively limited.

Effects of rasfonin on growth of K-ras mutant Panc- 1 cell xenograft tumors. After showing that rasfonin inhibits cell growth and transformation in vitro, we were interested in assessing its effect in vivo. Mice were treated with $7.5,15$ or $30 \mathrm{mg} / \mathrm{kg}$ rasfonin every 2 days for 3 consecutive weeks. Control mice were treated with either vehicle (negative
Table 1 Effect of rasfonin on the kinases activity (\%)

\begin{tabular}{lc}
\hline Protein kinase & Activity (\% control) \\
\hline Control & $100 \pm 2$ \\
EGFR & $113 \pm 3$ \\
FAK & $102 \pm 0$ \\
FGFR3 & $97 \pm 4$ \\
Flt3 & $98 \pm 3$ \\
Met & $113 \pm 0$ \\
PDGFR $\alpha$ & $105 \pm 1$ \\
PDGFR $\beta$ & $108 \pm 9$ \\
PKB $\alpha$ & $113 \pm 3$ \\
PKB $\beta$ & $98 \pm 2$ \\
PKB $\gamma$ & $117 \pm 6$ \\
c-RAF & $86 \pm 6$ \\
MEK1 & $90 \pm 2$ \\
IKK $\alpha$ & $114 \pm 11$ \\
JNK1 $\alpha 1$ & $93 \pm 2$ \\
JNK2 $\alpha 2$ & $116 \pm 3$ \\
mTOR & $112 \pm 13$ \\
p70S6K & $149 \pm 9$ \\
Ros & $106 \pm 2$ \\
PI3 kinase $(\mathrm{p} 110 a / p 85 a)$ & $99 \pm 4$ \\
\end{tabular}

Effects of rasfonin on EGFR family kinase activities. Kinase activities were measured using $\left[{ }^{32} \mathrm{P}\right]$ radiometric protein kinase assays after treatment with $5 \mu \mathrm{M}$ rasfonin and incubation for $40 \mathrm{~min}$. The results were expressed as percentage c.p.m. versus control (\% control) defined as ((sample - mean no enzyme $) /($ mean plus enzyme - mean no enzyme $)) \times 100$.

control group) or FTS (positive control group). Treatment was started when the tumor xenograft reached $\sim 200 \mathrm{~mm}^{3}$, and the effects of compounds on tumor growth are summarized in Figure 5a. Although the average tumor size increased from 244 to $979 \mathrm{~mm}^{3}$ in the control group (a fourfold increase), the average tumor size in the rasfonintreated group increased from $193 \mathrm{~mm}^{3}$ to $319 \mathrm{~mm}^{3}$, representing a relatively modest $(\mathrm{T} / \mathrm{C}=33 \%)$ but statistically significant reduction in tumor growth $67 \%$ tumor growth reduction; $P=0.019$ ). FTS was administered at doses and schedules reported to give optimal antitumor efficacy in some pancreatic tumor models, ${ }^{23}$ but it demonstrated no significant antitumor efficacy in the Panc-1 xenograft model: the \%T/C for that group, calculated on day 20 , was $52 \%$, representing a $48 \%$ reduction in tumor growth $(P=0.337)$. At the end of the experiment, the mice were killed and the xenograft tumors were extirpated and weighed. The average tumor weight in the rasfonin-treated group $(30 \mathrm{mg} / \mathrm{kg})$ was less than half of that in the control group $(P<0.05$; Figure $5 b)$.

\section{Discussion}

Rasfonin is a structurally novel 2-pyrone derivative isolated from the fermented mycelium of Talaromyces species 3656A1(13). Previous reports have revealed that rasfonin selectively induces apoptosis in ras-dependent cells and could represent a unique class of cancer chemotherapeutics useful for treating ras-mutant tumors. ${ }^{14}$ In this study we focused on the effects of rasfonin on pancreatic cancer because $90 \%$ pancreatic cancers exhibit K-ras mutations. We found that rasfonin suppressed proliferation, anchorage-independent growth, migration and invasion of $K$-ras mutant Panc-1 pancreatic cancer cells and caused mild growth suppression of wild-type K-ras BxPC-3. We extended our in vitro studies to 


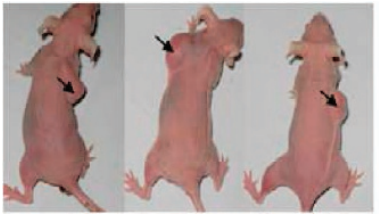

Control

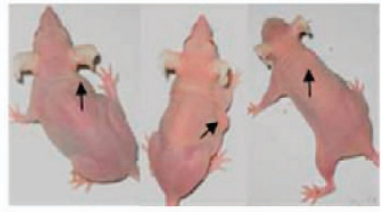

Rasfonin $30 \mathrm{mg} / \mathrm{kg}$

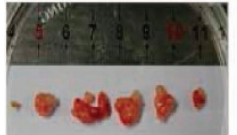

Control

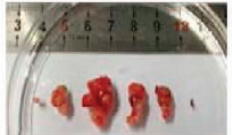

FTS 15 mg/kg

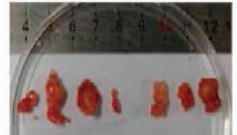

Rasfonin $7.5 \mathrm{mg} / \mathrm{kg}$

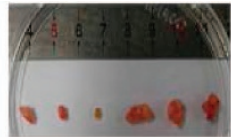

Rasfonin 15 mg/kg

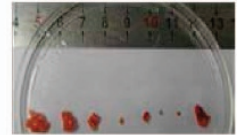

Rasfonin $30 \mathrm{mg} / \mathrm{kg}$
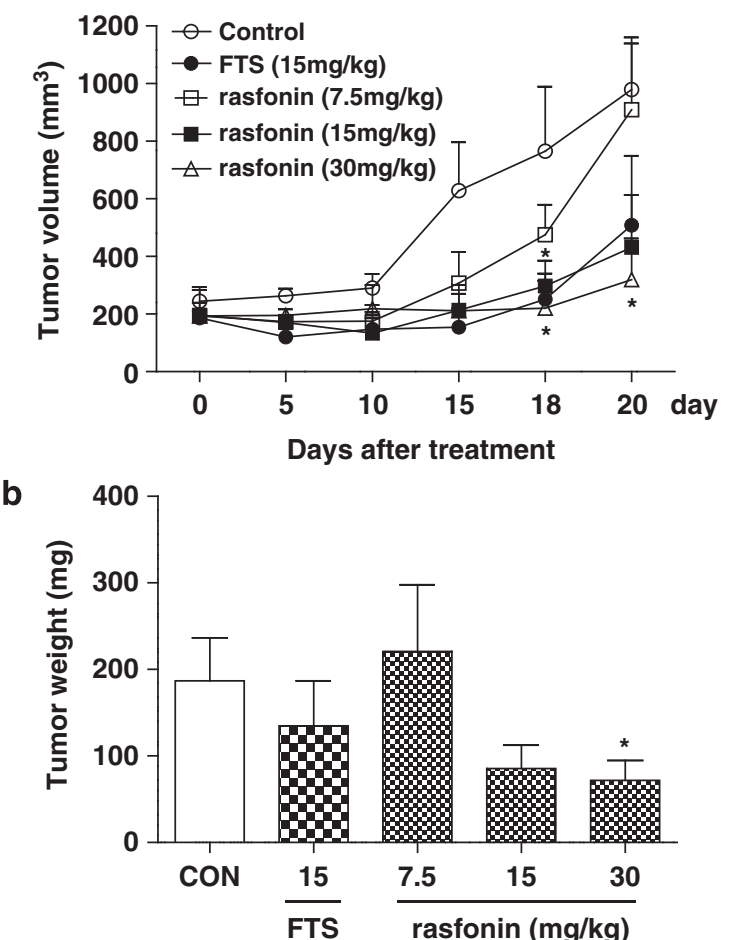

Figure 5 Effects of rasfonin on tumor volume and tumor weight in Panc-1 xenograft nude mice. Subcutaneous xenografts were established by injecting $1 \times 10^{7}$ Panc- 1 cells into the right flank of 6- to 7-week-old female nude mice. Rasfonin treatment was initiated when the tumors reached around $100-300 \mathrm{~mm}^{3}$. Three desired concentrations of rasfonin were administered once every 2 days for up to 20 days by intraperitoneal injection. FTS $(15 \mathrm{mg} / \mathrm{kg} / \mathrm{day})$ was administered once daily for up to 20 days by intraperitoneal injection. Tumor sizes were measured at least three times a week and the changes in individual mice were plotted against the time of treatment. The graph of each 5-day treatment indicated both the control and rasfonin-treated mice. (a) Tumor volume. (b) After 20 days of treatment, mice bearing Panc-1 tumors were killed and the tumor weight in each mouse was measured. ${ }^{*} P<0.05, n=6-8$

an in vivo Panc-1 xenograft tumor model on CD1 nude mice. Intraperitoneal rasfonin administration resulted in moderate but statistically significant antitumor activity with a $67 \%$ overall reduction of tumor growth compared with the vehicle control group. To our knowledge, this is the first report to demonstrate the unambiguous effect of rasfonin on K-ras mutant pancreatic cells and xenograft tumor mice.

In both our in vitro and in vivo studies, Salirasib (S-trans,trans-farnesylthiosalicylic acid, FTS) served as a positive control to evaluate the effects of rasfonin. FTS is a low molecular weight synthetic compound and a potent Ras inhibitor. ${ }^{20}$ It mimics the carboxy terminal of farnesylcysteine carboxymethyl ester, which is common to all Ras proteins and forms part of the recognition unit for anchorage, so it displaces active Ras protein from the cell membrane. ${ }^{20,24}$ FTS readily enters cells and specifically disrupts the association of active forms of Ras proteins with the inner surface of the membrane; this disturbance contributes to the inhibition of cell transformation and tumor growth. ${ }^{25-27}$ We chose FTS as a positive control because of its unique mechanism of action. Several previous studies have demonstrated that FTS decreases the cellular Ras protein level and inhibits Ras activation. ${ }^{28}$ Consistent with these studies, our results indicated that FTS reduced Ras protein expression robustly. In contrast, rasfonin did not affect Ras protein levels, though it suppressed Ras activation as FTS does. These data implied that rasfonin differs from FTS in mechanism of action.

Normal Ras proteins are continuously cycling between inactive (Ras-GDP) and active (Ras-GTP) conformations. Molecular activation triggered by different extracellular stimuli 
increases the intracellular Ras-GTP level and elicits a conformational change, enabling these GTPases to interact with downstream effector proteins. The kinetics of cellular Ras activation is modulated through different negative and positive regulators. The negative regulators include GTPase-activating proteins (Ras-GAPs), which enhance the intrinsic RasGTPase activity and elicit rapid hydrolysis of bound GTP. The positive regulators correspond to the guanine nucleotide exchange factors (Ras-GEFs) that stimulate release of bound GDP in exchange for GTP, so the active Ras-GTP complex accumulates in response to upstream stimuli. ${ }^{29}$ Overactive Ras can put the growth signaling pathway in an 'always on' state, even in the absence of incoming signals. In our study, to ascertain whether the restraint of proliferation of $\mathrm{K}$-rasmutated pancreatic cells could be, in part, due to a loss of Ras activation, a pull-down assay was used to study the effect of rasfonin on Ras-GTP in Panc-1 cells. The results indicated that Ras is already activated in the Panc- 1 cell line and EGF stimulation had an evident effect on Ras-GTP levels. Rasfonin treatment reduced EGF-induced Ras activation in a dose-dependent fashion but did not affect total Ras protein expression. These data confirmed previous studies demonstrating that rasfonin affects the Ras signaling pathway. To explore the potential mechanism of rasfonin action further, Ras-GAP and Ras-GEF activities were detected through $\left[{ }^{3} \mathrm{H}\right]$-GDP binding and dissociation. Interestingly, rasfonin affected neither Ras-GAP nor Ras-GEF activity, nor did it affect the protein expression of Ras-GAP or Grb2 (one ingredient of Ras-GEF). Indeed, among all the upstream Ras signaling molecules we measured, it only reduced the expression of Son of sevenless 1 (Sos1).

Sos 1 and Sos 2 belong to the Sos family. Mammalian Sos 1 and Sos 2 proteins have approximately $70 \%$ overall homology, are ubiquitously expressed and function by coupling signals originating from cell surface receptor tyrosine kinases (RTKs) to downstream, Ras-dependent mitogenic signaling pathways. Sos 1 is a dual GEF for Ras and interacts with the adaptor protein Grb2. ${ }^{30-32}$ The Grb2-Sos1 complex is recruited to phosphotyrosine residues of ligand-activated RTKs through the $\mathrm{SH} 2$ domain of Grb2. RTK activation thus results in the translocation of Sos 1 to the plasma membrane, where Ras is present, thereby facilitating Sos1-mediated Ras activation. ${ }^{33}$ Although aberrant expression of many downstream and upstream components of the Ras/ERK pathway is clearly associated with carcinogenesis, very few reports suggest a possible role for Sos genes in human proliferative pathologies. ${ }^{29,34}$ Indeed, screening studies indicate that Sos1 mutations are uncommon in human tumors. On the other hand, recent reports have described the enhanced expression of Sos1 in prostate cancer epithelial cells of African-American men. Depletion of Sos1 in PC3 and DU145 prostate cancer cells results in decreased capacities for cell proliferation, migration and invasion, so Sos 1 is considered a promising cancer therapy target. ${ }^{35}$ There has been no report to date concerning the effect of FTS on Sos1. However, we found that FTS indubitably reduced EGF-induced Sos 1 expression. Interestingly, rasfonin decreased Sos1 expression to the same extent. The underlying mechanism is still unknown and needs further investigation. In addition, we presume that apart from the Sos1 (GEF)-Ras cascade, the influence of rasfonin could be restricted because it had only marginal effects on the many protein kinases involved in the EGFR signaling pathway, except for p70S6k.

In conclusion, we found that the novel 2-pyrone derivative rasfonin is a promising lead compound for treating $\mathrm{K}$-ras mutation pancreatic cancer. Its unique mechanism of reducing Sos1 and consequently suppressing Ras-Raf-MEKERK activity needs to be further elucidated in future studies.

\section{Materials and Methods}

Animals. Female nude CD1-Nu mice, 6-7 weeks old, were obtained from Vital River Laboratory Animal Technology Co. Ltd (Beijing, China). The mice were housed in barrier facilities on a $12 \mathrm{~h}$ light/dark cycle. Food and water were supplied ad libitum. Mice were handled at the institute's (Institute of Pharmacology and Toxicology, Beijing, China) animal facility, and all treatments were in accordance with legal and institutional guidelines.

Cell lines and cell culture. Two pancreatic cancer cell lines, BxPC-3 (wild type K-ras) and Panc-1 (mutated K-ras) were used in this study. These cell lines were purchased from the American Type Culture Collection (Manassas, VA, USA). BxPC-3 cells were grown in RPMI-1640 and Panc- 1 cells in DMEM with high glucose containing $10 \%$ fetal calf serum (FCS), penicillin and streptomycin. Both cell lines were incubated in a $5 \% \mathrm{CO}_{2}$ humidified incubator at $37^{\circ} \mathrm{C}$. Rasfonin was isolated from the fungus Doratomyces $s p$. Salirasib was purchased from Cayman Chemical Company (Ann Arbor, MI, USA). All cell culture reagents and growth factors were purchased from Invitrogen Life technologies (New York, CA, USA). Anti-Sos1, anti-Grb2, anti-GAP, anti-MEK1/2, anti-ERK44/42, anti-Ras, antiphospho-c-Raf, anti-phospho-MEK1/2, anti-phospho-ERK44/42 and anti-GAPDH were purchased from Cell Signaling Technology (Danvers, MA, USA). $\left[{ }^{3} \mathrm{H}\right]-$ GDP was purchased from ARC. RasGEF and RasGAP were purchased from Origene (Rockville, MD, USA).

Cell viability assays. Cell viability was monitored by the xCELLigence system (Roche, Basel, Switzerland) and the MTS assay. The XCELLigence system is a real-time, non-labeled, impedance-based cell analysis system that allows cell adhesion, proliferation and migration to be monitored continuously and quantitatively. The cell-electrode impedance response generated from the interaction of cells with the electronic biosensors at the bottom of the culture plate was used to derive the cell index $(\mathrm{Cl})$. The $\mathrm{Cl}$ reflects overall cell number, attachment quality and cell morphology, which can change as a function of time. ${ }^{36}$ The protocol was as follows. First, the optimal seeding concentrations for experiments on Panc-1 and BxPC-3 cell proliferation were determined. After seeding, the number of cells in $100 \mu \mathrm{l}$ medium in each well of the 96-well E-plate was determined, and proliferation, attachment and spreading of the cells, were monitored every $15 \mathrm{~min}$ by the xCELLigence system. Approximately $4 \mathrm{~h}$ after seeding, when the cells were in the log growth phase, they were exposed to $50 \mu \mathrm{l}$ rasfonin (final concentrations $1,5,10,15 \mu \mathrm{M}$ ) or FTS (final concentration $50 \mu \mathrm{M}$ ). For controls an equivalent volume of medium was added. All detections were run for $40 \mathrm{~h}$.

For the MTS assay, exponentially growing cells were plated into 96-well plates, then treated with rasfonin $(1,5,10,15 \mu \mathrm{M})$ for $24 \mathrm{~h}$. At the end of the incubation, $20 \mu \mathrm{l}$ MTS (Promega, Madison, WI, USA) was added to each well and the plates were incubated for an additional $2 \mathrm{~h}$ at $37^{\circ} \mathrm{C}$. The absorbance at $570 \mathrm{~nm}$ was measured using an Enspire 2300 Multilabel Reader (Perkin Elmer, Waltham, MA, USA).

Contact-independent growth assays. Contact-independent growth was measured according to previous protocols. ${ }^{37,38}$ Briefly, exponentially growing Panc- 1 cells were trypsinized and $1 \times 10^{3}$ cells were added to triplicate wells in six-well plates. Rasfonin $(0.25,0.5,1,5 \mu \mathrm{M})$ was dissolved in DMEM and added to the wells. After 8 days in culture, live colonies were counted, stained with $0.05 \%$ crystal violet and photographed.

Migration and invasion assays. Migration and invasion were also examined with the xCELLigence system using specially designed 16-well plates (CIM-plate 16, Roche) with $8 \mu \mathrm{m}$ pores. These plates are similar to conventional transwells with the microelectrodes located on the underside of the membrane of the upper chamber. For the migration assay, $8.0 \times 10^{4}$ Panc-1 cells were seeded 
in the upper chamber with rasfonin or FTS. This upper chamber was then placed on the lower part of the CIM-device containing growth medium supplemented with $10 \%$ FBS as an attractant or without FBS (negative control). Cell migration was followed for up to $24 \mathrm{~h}$ by changes of the impedance signal measured on the lower face of the upper chamber membrane. ${ }^{39,40}$ Cell invasion was also assessed using the CIM-plate. Before the cells were seeded, the surface of the upper chamber was coated with Matrigel (BD BioSciences, Franklin Lake, NJ, USA). Then $10 \%$ FBS was added to the lower chamber and the cells were seeded into the upper chamber at $80000 /$ well. The $\mathrm{Cl}$ in the $16 \mathrm{CIM}$-plate was monitored every $15 \mathrm{~min}$ for $24 \mathrm{~h}$. Data were analyzed using the RTCA Software 1.2 supplied with the instrument. ${ }^{41}$

KinaseProfiler radiometric protein kinase assays. Protein kinases were incubated with $8 \mathrm{mM}$ MOPS, pH 7.0, $0.2 \mathrm{mM}$ EDTA, $10 \mathrm{mM} \mathrm{MnCl} 2,10 \mathrm{mM}$ $\mathrm{Mg}$ acetate and $\left[\gamma^{32}\right.$ P-ATP] (specific activity $\sim 500$ c.p.m./pmol, concentration as required) for $40 \mathrm{~min}$ at room temperature. The reaction was initiated by adding the MgATP mix. After incubation, the reaction was stopped by adding 3\% phosphoric acid. Ten microliters of the reaction product was spotted on to a Filtermat $A$ and washed three times for $5 \mathrm{~min}$ in $75 \mathrm{mM}$ phosphoric acid and once in methanol before drying and scintillation counting.

Ras activation assays. The Ras Activation ELISA Assay Kit (Millipore, Billerica, MA, USA) works on the principle that Ras only binds to its downstream kinase, c-Raf (MAP Kinase Kinase Kinase), when in its active-GTP-bound state. In this state, Ras binds to a domain of $c$-Raf kinase referred to as the ras-binding domain (RBD). A recombinant $\mathrm{c}-\mathrm{Raf}-\mathrm{RBD}$ is provided for the capture of activated Ras from the sample. C-Raf-RBD binds to the wells of a 96-well glutathionecoated ELISA plate via a GST/glutathione interaction, thus capturing the active Ras and allowing the inactive/GDP-bound Ras to be washed away. The captured active Ras is detected and measured quantitatively through the addition of a monoclonal anti-Ras antibody. An HRP-conjugated secondary antibody is then added for detection. Following addition of the chemiluminescent substrate, signals can be measured using a luminometer. Panc-1 cells were cultured in DMEM supplemented with $10 \%$ FBS for $18 \mathrm{~h}$, starved for $9 \mathrm{~h}$ in DMEM, $0.1 \%$ FBS, and then treated for $12 \mathrm{~h}$ with different concentrations of rasfonin. They were then stimulated with EGF $(50 \mathrm{ng} / \mathrm{ml})$ for $5 \mathrm{~min}$ and lysed in the lysis buffer provided by the manufacturer. The total protein was quantified, and $50 \mu \mathrm{g}$ of total protein was used for the assay following the manufacturer's directions. Both positive and negative controls were provided in the kit.

Western blotting assays. Panc- 1 cells were cultured in DMEM supplemented with $10 \%$ FBS for $18 \mathrm{~h}$, starved for $9 \mathrm{~h}$ in DMEM with $0.1 \% \mathrm{FBS}$ and then treated for $12 \mathrm{~h}$ with different concentrations of rasfonin. They were then stimulated with EGF $(50 \mathrm{ng} / \mathrm{ml})$ for $5 \mathrm{~min}$, washed twice with PBS, lysed with lysis buffer containing phosphatase inhibitor cocktail and protease inhibitor cocktail (Roche), and cleared by centrifugation at $16000 \times g$ for $15 \mathrm{~min}$. Proteins $(20-50 \mu \mathrm{g})$ were subjected to electrophoresis and transferred to nitrocellulose membranes, blocked in 5\% nonfat dry milk in TBST and probed with anti-Sos1, anti-Grb2, anti-GAP, anti-MEK1/2, anti-ERK44/42, anti-Ras, anti-phospho-c-Raf, anti-phospho-MEK1/2, anti-phospho-ERK44/42 and anti-GAPDH. Primary antibodies were detected with the horseradish peroxidase-conjugated secondary antibodies and chemiluminescent HRP substrate (Thermo Fisher Scientific Inc, Waltham, MA, USA).

GEF and GAP activity assays. To examine the effect of GEF on $\left[{ }^{3} \mathrm{H}\right]-\mathrm{GDP}$ dissociation from Ras or GAP on [ $\left.{ }^{3} \mathrm{H}\right]-\mathrm{GDP}$ binding to Ras, $42 \mathrm{pmol}$ of Ras was preloaded with $2 \mu \mathrm{Ci}\left[{ }^{3} \mathrm{H}\right]$-GDP and $10 \mu \mathrm{l}$ GTP. Simultaneously, GEF or GAP was incubated in the absence or presence of rasfonin $(10 \mu \mathrm{M})$ for $2 \mathrm{~h}$ in $20 \mathrm{mM}$ Tris$\mathrm{HCl}, \mathrm{pH} 7.5,0.1 \mathrm{mM}$ DTT, $80 \mathrm{mM} \mathrm{NaCl}, 0.5 \mathrm{mM} \mathrm{MgCl}_{2}$ ( $80 \mu$ l volume). Preloaded $\left[{ }^{3} \mathrm{H}\right]$-GDP-bound Ras samples were mixed with the preceding buffer containing GEF or GAP (100 $\mu$ l volume) for $30 \mathrm{~min}$. The reaction product was spotted on Millipore BA85, air-dried and washed $\times 3$ for 5 min with ice-cold $20 \mathrm{mM}$ Tris- $\mathrm{HCl}$, $\mathrm{pH} 7.5,100 \mathrm{mM} \mathrm{NaCl}, 10 \mathrm{mM} \mathrm{MgCl}_{2}$. The amount of $\left[{ }^{3} \mathrm{H}\right]$-GDP-bound to Ras was measured by scintillation spectrometry.

In vivo anticancer efficacy. On day $0,1 \times 10^{7}$ Panc- 1 cells in $0.1 \mathrm{ml}$ of PBS were implanted subcutaneously into a mouse just above the right armpit. Tumor diameters were serially measured with a digital caliper every 2-3 days. Therapy was started after 1 week when the tumors had reached an average volume of $100 \mathrm{~mm}^{3}$. The animals were randomized into five groups $(n=6-8)$ : (A) control; (B) FTS (15 mg/kg, every day); (C) rasfonin (7.5 mg/kg); (D) rasfonin $(15 \mathrm{mg} / \mathrm{kg})$; (E) rasfonin $(30 \mathrm{mg} / \mathrm{kg})$. Rasfonin was administered by intraperitoneal injection every 2 days for 3 consecutive weeks. Tumor diameters were serially measured, and tumor volumes were calculated using the following formula: $\mathrm{V}=\left(\mathrm{L} \times \mathrm{W}^{2}\right) / 2$, where $\mathrm{V}=$ volume (in cubic millimeters), $\mathrm{L}=$ length (in millimeters), and $W=$ width (in millimeters). After 20 days of treatment, the tumors were resected and weighed. The efficacy of treatment was assessed as treated/control, defined as (median treated tumor volume/median control tumor volume $\times 100)$ and expressed as a percentage $(\% \mathrm{~T} / \mathrm{C})$. Tumor growth reduction was calculated by subtracting the $\% \mathrm{~T} / \mathrm{C}$ from 100 .

Statistical analysis. Unless otherwise stated, data are expressed as mean \pm S.E.M. One-way analysis of variance (ANOVA) was used to assess significant differences between groups. Dunnett's multiple comparisons test was used to test significant effects among multiple group means.

\section{Conflict of Interest}

Beijing Institute of Pharmacology \& Toxicology holds the patent of the preparation methods of title compound rasfonin. The authors work for Beijing Institute of Pharmacology \& Toxicology.

Acknowledgements. This work was supported by the National Natural Science Foundation of China $(81202416,81001652)$ and the Chinese Scientific and Technological Major Special Project (2012ZX09301003-001, 002).

1. Bustinza-Linares $E$, Kurzrock $R$, Tsimberidou AM. Salirasib in the treatment of pancreatic cancer. Future Oncol 2010; 6: 885-891.

2. Abbruzzese JL. New applications of gemcitabine and future directions in the management of pancreatic cancer. Cancer 2002; 95: 941-945.

3. Yip-Schneider MT, Sweeney CJ, Jung SH, Crowell PL, Marshall MS. Cell cycle effects of nonsteroidal anti-inflammatory drugs and enhanced growth inhibition in combination with gemcitabine in pancreatic carcinoma cells. J Pharmacol Exp Ther 2001; 298: 976-985.

4. Hezel AF, Kimmelman AC, Stanger BZ, Bardeesy N, Depinho RA. Genetics and biology of pancreatic ductal adenocarcinoma. Genes Dev 2006; 20: 1218-1249.

5. Talar-Wojnarowska R, Malecka-Panas E. Molecular pathogenesis of pancreatic adenocarcinoma: potential clinical implications. Med Sci Monit 2006; 12: RA186-RA193.

6. Bardeesy N, DePinho RA. Pancreatic cancer biology and genetics. Nat Rev Cancer 2002; 2: 897-909.

7. Watanabe M, Nobuta A, Tanaka J, Asaka M. An effect of K-ras gene mutation on epidermal growth factor receptor signal transduction in PANC-1 pancreatic carcinoma cells. Int J Cancer 1996; 67: 264-268.

8. Chardin P, Camonis JH, Gale NW, van Aelst L, Schlessinger J, Wigler MH et al. Human Sos1: a guanine nucleotide exchange factor for Ras that binds to GRB2. Science 1993; 260: 1338-1343.

9. Buday L, Downward J. Epidermal growth factor regulates the exchange rate of guanine nucleotides on p21ras in fibroblasts. Mol Cell Biol 1993; 13: 1903-1910.

10. Bos JL. ras oncogenes in human cancer: a review. Cancer Res 1989; 49: 4682-4689.

11. Xu GF, O'Connell P, Viskochil D, Cawthon R, Robertson M, Culver M et al. The neurofibromatosis type 1 gene encodes a protein related to GAP. Cell 1990; 62: 599-608.

12. McCormick F. ras GTPase activating protein: signal transmitter and signal terminator. Cell 1989; 56: 5-8.

13. Tomikawa T, Shin-Ya K, Furihata K, Kinoshita T, Miyajima A, Seto H et al. Rasfonin, a new apoptosis inducer in ras-dependent cells from Talaromyces sp. J Antibiot (Tokyo) 2000; 53: 848-850.

14. Boeckman RK Jr, Pero JE, Boehmler DJ. Toward the development of a general chiral auxiliary. Enantioselective alkylation and a new catalytic asymmetric addition of silyloxyfurans: application to a total synthesis of ( - )-rasfonin. J Am Chem Soc 2006; 128: 11032-11033.

15. Alcock RA, Dey S, Chendil D, Inayat MS, Mohiuddin M, Hartman G et al. Farnesyltransferase inhibitor (L-744,832) restores TGF-beta type II receptor expression and enhances radiation sensitivity in K-ras mutant pancreatic cancer cell line MIA PaCa-2. Oncogene 2002; 21: 7883-7890.

16. Krzysiak AJ, Rawat DS, Scott SA, Pais JE, Handley M, Harrison ML et al. Combinatorial modulation of protein prenylation. ACS Chem Biol 2007; 2: 385-389.

17. Barnard D, Diaz B, Hettich L, Chuang E, Zhang XF, Avruch J et al. Identification of the sites of interaction between c-Raf-1 and Ras-GTP. Oncogene 1995; 10: 1283-1290.

18. Nassar N, Horn G, Herrmann C, Block C, Janknecht R, Wittinghofer A. Ras/Rap effector specificity determined by charge reversal. Nat Struct Biol 1996; 3: 723-729.

19. Pumiglia K, Chow YH, Fabian J, Morrison D, Decker S, Jove R. Raf-1 N-terminal sequences necessary for Ras-Raf interaction and signal transduction. Mol Cell Biol 1995; 15: 398-406. 
20. Haklai R, Elad-Sfadia G, Egozi Y, Kloog Y Orally administered FTS (salirasib) inhibits human pancreatic tumor growth in nude mice. Cancer Chemother Pharmacol 2008; 61 89-96.

21. Goldberg L, Haklai R, Bauer V, Heiss A, Kloog Y. New derivatives of farnesylthiosalicylic acid (salirasib) for cancer treatment: farnesylthiosalicylamide inhibits tumor growth in nude mice models. J Med Chem 2009; 52: 197-205.

22. Faigenbaum R, Haklai R, Ben-Baruch G, Kloog Y. Growth of poorly differentiated endometrial carcinoma is inhibited by combined action of medroxyprogesterone acetate and the Ras inhibitor Salirasib. Oncotarget 2013; 4: 316-328.

23. Gana-Weisz M, Halaschek-Wiener J, Jansen B, Elad G, Haklai R, Kloog Y. The Ras inhibitor S-trans,trans-farnesylthiosalicylic acid chemosensitizes human tumor cells without causing resistance. Clin Cancer Res 2002; 8: 555-565.

24. Blum R, Kloog Y. Tailoring Ras-pathway-inhibitor combinations for cancer therapy. Drug Resist Updat 2005; 8: 369-380.

25. Haklai R, Weisz MG, Elad G, Paz A, Marciano D, Egozi $Y$ et al. Dislodgment and accelerated degradation of Ras. Biochemistry 1998; 37: 1306-1314.

26. Jansen B, Schlagbauer-Wadl H, Kahr H, Heere-Ress E, Mayer BX, Eichler $\mathrm{H}$ et al. Novel Ras antagonist blocks human melanoma growth. Proc Natl Acad Sci USA 1999; 96 : 14019-14024.

27. Elad G, Paz A, Haklai R, Marciano D, Cox A, Kloog Y. Targeting of K-Ras 4B by S-trans,trans-farnesyl thiosalicylic acid. Biochim Biophys Acta 1999; 1452: 228-242.

28. Goldberg L, Kloog Y. A Ras inhibitor tilts the balance between Rac and Rho and blocks phosphatidylinositol 3-kinase-dependent glioblastoma cell migration. Cancer Res 2006; 66 : 11709-11717.

29. Rojas JM, Oliva JL, Santos E. Mammalian son of sevenless Guanine nucleotide exchange factors: old concepts and new perspectives. Genes Cancer 2011; 2: 298-305.

30. Nimnual A, Bar-Sagi D.. The two hats of SOS. Sci STKE 2002; 2002: pe36.

31. Nimnual AS, Yatsula BA, Bar-Sagi D. Coupling of Ras and Rac guanosine triphosphatases through the Ras exchanger Sos. Science 1998; 279: 560-563.

32. Bar-Sagi D. The Sos (Son of sevenless) protein. Trends Endocrinol Metab 1994; 5: 165-169

33. Hwang HS, Hwang SG, Cho JH, Chae JS, Yoon KW, Cho SG et al. CIIA functions as a molecular switch for the Rac1-specific GEF activity of SOS1. J Cell Biol 2011; 195: 377-386.

34. Pierre S, Bats AS, Coumoul X. Understanding SOS (Son of Sevenless). Biochem Pharmacol 2011; 82: 1049-1056.
35. Timofeeva OA, Zhang X, Ressom HW, Varghese RS, Kallakury BV, Wang $\mathrm{K}$ et al. Enhanced expression of SOS1 is detected in prostate cancer epithelial cells from African-American men. Int J Oncol 2009; 35: 751-760.

36. Urcan E, Haertel U, Styllou M, Hickel R, Scherthan H, Reichl FX. Real-time xCELLigence impedance analysis of the cytotoxicity of dental composite components on human gingival fibroblasts. Dent Mater 2010; 26: 51-58.

37. Campbell PM, Boufaied N, Fiordalisi JJ, Cox AD, Falardeau P, Der CJ et al. TLN-4601 suppresses growth and induces apoptosis of pancreatic carcinoma cells through inhibition of Ras-ERK MAPK signaling. J Mol Signal 2010; 5: 18

38. Campbell PM, Groehler AL, Lee KM, Ouellette MM, Khazak V, Der CJ. K-Ras promotes growth transformation and invasion of immortalized human pancreatic cells by Raf and phosphatidylinositol 3-kinase signaling. Cancer Res 2007; 67: 2098-2106.

39. Weisz B, Giehl K, Gana-Weisz M, Egozi Y, Ben-Baruch G, Marciano D et al. A new functional Ras antagonist inhibits human pancreatic tumor growth in nude mice. Oncogene 1999; 18: 2579-2588.

40. Roshan Moniri M, Young A, Reinheimer K, Rayat J, Dai LJ, Warnock GL. Dynamic assessment of cell viability, proliferation and migration using real time cell analyzer system (RTCA). Cytotechnology 2014; doi:10.1007/s10616-014-9692-5.

41. Keogh RJ. New technology for investigating trophoblast function. Placenta 2010; 31: 347-350

cC)(-) Cell Death and Disease is an open-access journal published by Nature Publishing Group. This work is licensed under a Creative Commons Attribution-NonCommercialShareAlike 3.0 Unported License. The images or other third party material in this article are included in the article's Creative Commons license, unless indicated otherwise in the credit line; if the material is not included under the Creative Commons license, users will need to obtain permission from the license holder to reproduce the material. To view a copy of this license, visit http://creativecommons.org/licenses/ by-nc-sa/3.0/ 